Michelle A. Clark is an economist at the Federal Reserve Bank of St. Louis. Thomas A. Pollmann provided research assistance.

\title{
Eighth District Banks in 1989: In the Eye of a Storm?
}

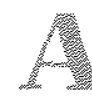

FTER REBOUNDING sharply in 1988, most commercial banks in the Eighth Federal Reserve District experienced modest increases in profitability in 1989 and continued to outperform their national counterparts. ${ }^{1}$ With few exceptions, Eighth District banks were largely unscathed by the rough weather which battered some segments of the industry, especially losses from real estate loans and loans to lesser-developed countries (LDCs), which depressed earnings at many of the nation's largest banks.

The performance of Eighth District commercial banks in 1989 vs. their national peers is analyzed in this paper, ${ }^{2}$ Conventional performance measures, including bank earnings, asset quality and capital adequacy, are examined to assess the financial condition and operating soundness of the District's banking industry. In addition, the compositions of assets and liabilities at District and U.S. banks are compared to explain why District bank performance ratios differ from those of their national peers.

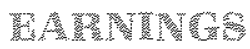

Eighth District banks earned $\$ 1.14$ billion in 1989, an increase of 1.7 percent from 1988 earnings of $\$ 1.12$ billion. Earnings for all U.S. banks of comparable size were $\$ 14.54$ billion in 1989, up 7 percent from 1988. Earnings for the entire banking industry fared poorly in 1989, however, because of the subpar performance of the 43 banks with total assets greater than $\$ 10$ billion; including these 43 banks, 1989 earnings totaled $\$ 15.86$ billion, down 35.4 percent from 1988 earnings of $\$ 24.56$ billion.

The number of District banks reporting losses for the year fell again in 1989: just 50 banks, or 4 percent of the District total, incurred losses in 1989 compared with 79 banks (6.1 percent) in 1988 and 88 banks ( 6.7 percent) in 1987 . Nationally, 11.3 percent of commercial banks with assets of less than $\$ 10$ billion-banks comparable in size to Eighth District banks-reported losses in 1989, down from 14.4 percent in 1988 and 18.5 percent in 1987; slightly more than 25
The Eighth Federal Reserve District comprises the following: Arkansas, entire state; Illinois, southern 44 counties; Indiana, southem 24 counties; Kentucky, western 64 counties; Mississippi, northern 39 counies; Missouri, eastem and southern 71 counties and the City of St. Louis; Tennessee, western 21 counties.

2Unless otherwise noted, performance ratios for all U.S. banks exclude those banks with assets of more than
$\$ 10$ billion, as there are no District banks of that size. See Karrenbrock (1990) for a detaled analysis of District agricultural bank performance in 1989. For bank performance statistics on each Eighth District state, see Clark (forthcoming). 
percent of banks with assets greater than $\$ 10$ billion reported net losses in 1989, up dramatically from 5.1 percent in 1988 . Substantial increases in loan loss provisions were primarily responsible for the increase in the proportion of large banks incurring losses in $1989 .^{3}$

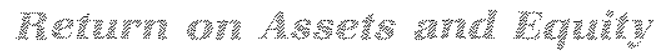

When examining bank earnings, two standard profitability measures generally are employed: the return on average assets (ROA) ratio and the return on equity (ROE) ratio. ROA, calculated by dividing a bank's net income by its average annual assets, indicates how successfully bank management employed the bank's assets to earn income. ROE, the ratio of a bank's net income to its equity capital, provides shareholders with a measure of the institution's return on their investment. ${ }^{4}$

As table 1 indicates, Eighth District banks recorded an average ROA of 0.88 percent and an average RoE of 11.26 percent in 1989. Both measures were down from their 1988 levels because of a sharp drop in profitability among the District's largest banks. Average ROA and ROE for the District's 13 banks with assets of $\$ 1$ to $\$ 10$ billion fell from 0.82 percent to 0.61 percent and from 12.46 percent to 9.53 percent, respectively, over the period.

District banks in asset categories of less than $\$ 1$ billion, however, generally experienced small average increases in ROA and ROE from 1988 to 1989 . District banks in the $\$ 25$ million to $\$ 300$ million asset range, which comprise about two-thirds of all District banks, did somewhat better, experiencing an average 5 percent increase in ROA in 1989 and a 3.4 percent in. crease in ROE. For the nearly two-thirds of U.S. banks in this same asset category, the improvements in ROA and ROE from 1988 to 1989 were even more substantial: 20.2 percent and 17 percent, respectively. The smallest U.S. banks, those with assets of less than $\$ 25$ million, experienced a 100 percent increase in ROA and a 97.9 percent increase in ROE in 1989; ROA and ROE for District banks in this asset category changed little from their 1988 levels.

Even though most U.S. banks showed stronger earnings improvement than their District counterparts, District banks continued to outperform their national peers in 1989: the national aver. ages of 0.74 percent ROA and 10.25 percent POE remained below the levels achieved by District banks. Across asset categories, only District banks in the $\$ 1$ billion to $\$ 10$ billion range registered average ROA and ROE below that of their national counterparts. Earnings were depressed or negative for some District banks in that asset category because of large additions to loan loss provisions associated with commercial real estate loans and loans to LDCs, ${ }^{5}$

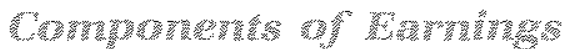

As with any business entity, a bank's financial success is determined by how much revenue its activities generate over and above the costs incurred in generating that revenue. In assessing the eamings performance of banks, analysts typically examine the three major components of income and expense: net interest income, net noninterest income and the loan loss provision. These components, like net income, are typically adjusted by average assets to ease comparison among banks. An analysis of these individual items permits a more precise determination as to why an institution experienced a profit or a loss in any period.

Pes gin is calculated by dividing the difference beween interest income (what a bank earned on loans and invesments) and interest expense (what it paid its depositors) by average earning 3il should be noted that increases in provisions for loan losses by the nation's largest banks in 1989 latgely rellect problem loans to LDCs and more recent problems with real estate lending. These losses will not nocessarily affect flutute protitability.

Equin capital consists of common and perpetua preforred stock, surphus, undivided profts and capital reserves and cumulative soreign currency transiation adjustments.

5U.S. banks with assets greater than $\$ 10$ billion had an even rougher year in 1989 , with average ROA of just 0.11 percent comparod wh 0.94 percent in 1988 and ROE of 2.20 percent compared with 18.84 percent in 1988. 
Table 1

\begin{tabular}{|c|c|c|c|c|c|c|c|c|}
\hline \multirow[b]{3}{*}{ Asset category } & \multicolumn{6}{|c|}{ Retum on Average Assets (ROA) } & \multirow{2}{*}{\multicolumn{2}{|c|}{1986,}} \\
\hline & \multicolumn{2}{|c|}{1989} & \multicolumn{2}{|c|}{1988} & \multicolumn{2}{|c|}{ ?ै। 1987} & & \\
\hline & $\begin{array}{l}\text { Eighth } \\
\text { District }\end{array}$ & $\begin{array}{l}\text { United } \\
\text { States. }\end{array}$ & $\begin{array}{l}\text { Eighth } \\
\text { District }\end{array}$ & $\begin{array}{l}\text { United } \\
\text { States }\end{array}$ & $\begin{array}{l}\text { Eighth } \\
\text { District }\end{array}$ & $\begin{array}{l}\text { United } \\
\text { States }\end{array}$ & $\begin{array}{l}\text { Eighth } \\
\text { District }\end{array}$ & $\begin{array}{l}\text { United } \\
\text { States }\end{array}$ \\
\hline All bankst & $0.88 \%$ & $0.74 \%$ & $0.92 \%$ & $0.72 \%$ & $0,80 \%$ & $0.54 \%$ & $087 \%$ & $0.65 \%$ \\
\hline Less than $\$ 25$ million & 0.81 & 0.58 & 0.81 & 0.29 & 0.68 & 014 & 0.68 & 0.02 \\
\hline$\$ 25-\$ 50$ million & 0.98 & 0.74 & 0.94 & 0.59 & 0.89 & 0.45 & 0.84 & 0.44 \\
\hline$\$ 50-\$ 100$ million & 1.06 & 0.88 & 1.01 & 0.76 & 0.93 & 0.64 & 0.92 & 0.60 \\
\hline$\$ 100-\$ 300$ milion & 102 & 0.92 & 0.96 & 0.78 & 0.94 & 0.74 & 0.87 & 0.69 \\
\hline$\$ 300$ million-\$1 bilion & 103 & 0.83 & 1.01 & 0.61 & 1.07 & 0.57 & 0.66 & 0.59 \\
\hline biltion & 0.61 & 0.65 & 0,82 & 0.77 & 0.51 & 0.48 & 0.98 & 0.76 \\
\hline
\end{tabular}

10 billion

\section{Return on Equity (ROE)}

\begin{tabular}{|c|c|c|c|c|c|c|c|}
\hline \multicolumn{2}{|c|}{1989} & \multicolumn{2}{|c|}{1988} & \multicolumn{2}{|c|}{1987} & \multicolumn{2}{|c|}{1986} \\
\hline $\begin{array}{l}\text { Elghth } \\
\text { olstrict }\end{array}$ & $\begin{array}{l}\text { United } \\
\text { States }\end{array}$ & $\begin{array}{l}\text { Eighth } \\
\text { olstict }\end{array}$ & $\begin{array}{l}\text { onted } \\
\text { states }\end{array}$ & $\begin{array}{l}\text { Eighth } \\
\text { District }\end{array}$ & $\begin{array}{l}\text { United } \\
\text { States }\end{array}$ & $\begin{array}{l}\text { Elghth } \\
\text { District }\end{array}$ & $\begin{array}{l}\text { United } \\
\text { States }\end{array}$ \\
\hline $1126 \%$ & $1025 \%$ & 111600 & $10.04 \%$ & $1024 \%$ & $754 \%$ & $11.25 \%$ & \\
\hline 8.30 & 5.74 & 8.27 & 290 & 7,17 & 1309 & 733 & 017 \\
\hline 10.67 & 8,11 & 10.46 & 6.69 & 1005 & 514 & 9.76 & 5.09 \\
\hline 1182 & 10.09 & 11,52 & 890 & 1074 & 775 & 1089 & 744 \\
\hline 12.65 & 1150 & 11.82 & 997 & (171) & 965 & Y1.08 & 926 \\
\hline 1297 & 1140 & 1295 & 878 & 1367 & 8.15 & 8.01 & 8.44 \\
\hline 9.53 & 10,16 & 12,46 & 1208 & 796 & 7.59 & 1459 & 1173 \\
\hline
\end{tabular}

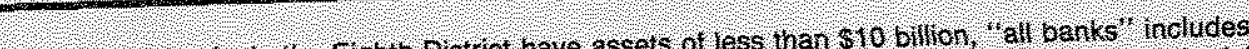

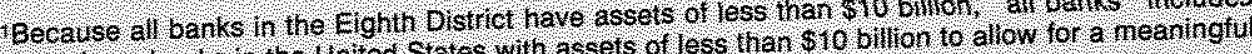

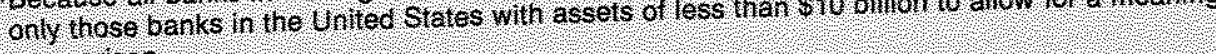
comparison.

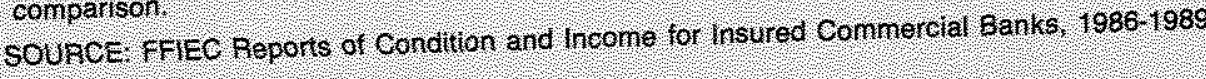

assets. ${ }^{6}$ As specified in table 2, District banks in 1989 posted their lowest net interest margin of the four years shown. The net interest margin fell 3 basis points from 1988 to 1989 for all District banks, largely because of the 15 basispoint decline for banks in the $\$ 1$ billion to $\$ 10$ billion asset category.
In contrast to other performance indicators, the net interest margin is one area in which U.S. banks consistently outperform their District peers. For U.S. banks with assets of less than $\$ 10$ billion, the average net interest margin in 1989 was 4.44 percent, up 2 basis points from 1988 and 31 basis points higher than the Dis-
6More precisely, interest income comprises the interest and fees realized from interestearning assets and includes such items as interest and points on loans, interest and such items as interest and points on loans, ind from securties holdings, and interest from divends from socuring accounts. Interest expense includes the interest paid on all categories of interest-bearing deposits, the expenses incurred in purchasing federal deposis, the expecurities under agreement to repurfunds and seling securies under agreent Average earning chase and interest paverage assets are used in the net inassets rather than average assets are used in the net ina return in the form of interest is generaied. 
Table 2

Net Interest Margin

\begin{tabular}{|c|c|c|c|c|c|c|c|c|}
\hline \multirow[b]{2}{*}{ Asset category } & \multicolumn{2}{|c|}{1989} & \multicolumn{2}{|c|}{1988} & \multicolumn{2}{|c|}{1987} & \multicolumn{2}{|c|}{1986} \\
\hline & $\begin{array}{l}\text { Eighth } \\
\text { District }\end{array}$ & $\begin{array}{l}\text { United } \\
\text { States }\end{array}$ & $\begin{array}{l}\text { Elghth } \\
\text { District }\end{array}$ & $\begin{array}{l}\text { United } \\
\text { States }\end{array}$ & $\begin{array}{l}\text { Eighth } \\
\text { District. }\end{array}$ & $\begin{array}{l}\text { United } \\
\text { States }\end{array}$ & $\begin{array}{l}\text { Eighth } \\
\text { Distfict }\end{array}$ & $\begin{array}{l}\text { United } \\
\text { States }\end{array}$ \\
\hline All banks & $413 \%$ & $444 \%$ & $4.16 \%$ & $442 \%$ & $427 \%$ & $4.48 \%$ & $440 \%$ & $4.49 \%$ \\
\hline Less than $\$ 25$ million & 4,27 & 455 & 428 & 451 & 445 & 4,61 & 4.68 & 473 \\
\hline$\$ 25-\$ 50$ million & 422 & 455 & 422 & 449 & 434 & 459 & 456 & 4.75 \\
\hline$\$ 50-\$ 100$ million & 4.14 & 4.52 & 412 & 449 & 433 & 4.59 & 456 & 477 \\
\hline$\$ 100 \$ 300$ million & 420 & 4.60 & 4,17 & 4.51 & 439 & 4.59 & 4,45 & 468 \\
\hline$\$ 300$ million $\$ 1$ billion & 4.42 & 457 & 4,37 & 446 & 4,55 & 4.56 & 4,46 & 4.65 \\
\hline$\$ 1 \$ 10$ billon & 389 & 432 & 4.04 & 4,35 & 3.97 & 436 & 414 & 425 \\
\hline
\end{tabular}

All banks heludes only those banks with assets of less than $\$ 10$ bilion.

NOTE Interest income has been adjusted upward by the taxable equivalence of tax-exempt state and local securities:

SOURCE, FFIEC Reports of Condition and Income for lnsured Conmercial Banks, $1986-1989$

trict average of 4.13 percent. U.S. banks posted higher net interest margins than District banks in every comparable asset category for all four years shown in table $2 .^{7}$

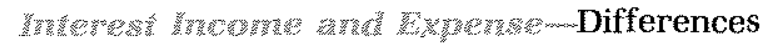
in net interest margins among banks in different asset classes and geographic areas can be explained by looking at the income and expense components of the ratio. As figure 1 illustrates, interest income as a percent of average earning assets for District banks averaged 10.25 percent in 1989, up sharply from the 1988 ratio of 9.53 percent. District banks with assets of less than $\$ 100$ million posted increases in interest income margins ranging from 4.5 percent to 6.3 percent; those with assets of more than $\$ 100$ million posted increases of 7.8 percent to 9.1 percent.

As in 1988, interest income as a percent of average earning assets was positively related to bank size in 1989. The greater interest incomeearning ability of larger banks can be explained by their tendency to hold less of their assets in relatively low-return securities than in relatively high-return loans compared with the smaller banks. The relative proportions of securities and loans in their asset portfolios also account for much of the margin differences between District banks and their U.S. counterparts. Across all asset categories, District banks held a larger proportion of their assets in the form of securities than did their national peers over the 1987-89 period.

Figure 1 also indicates that interest expense increased more than interest income in 1989. While interest income as a percent of average earning assets increased 7.6 percent at District banks in 1989, the interest expense ratio advanced 14 percent. Most of the increase in in" terest expense occurred in the first part of 1989, when rates paid on deposits and other interest-bearing liabilities were higher because of relatively restrictive monetary policy and competition from troubled thrifts that were offering high rates to meet their funding requirements. Because the average maturity of bank

\footnotetext{
The story is different for the large U.S. banks. The average net interest margin for banks with assets greater than $\$ 10$ billion fell 9.5 percent in 1989 to 3.43 percent. Jhis 36 basis-point decline pulled down the net interest margin for the U.S. banking industry in 1989 to 4.07 from 4.19 in 1988.
} 


\section{Figure 1}

\section{Interest Income and Interest Expense as a Percent of Average Earning Assets}

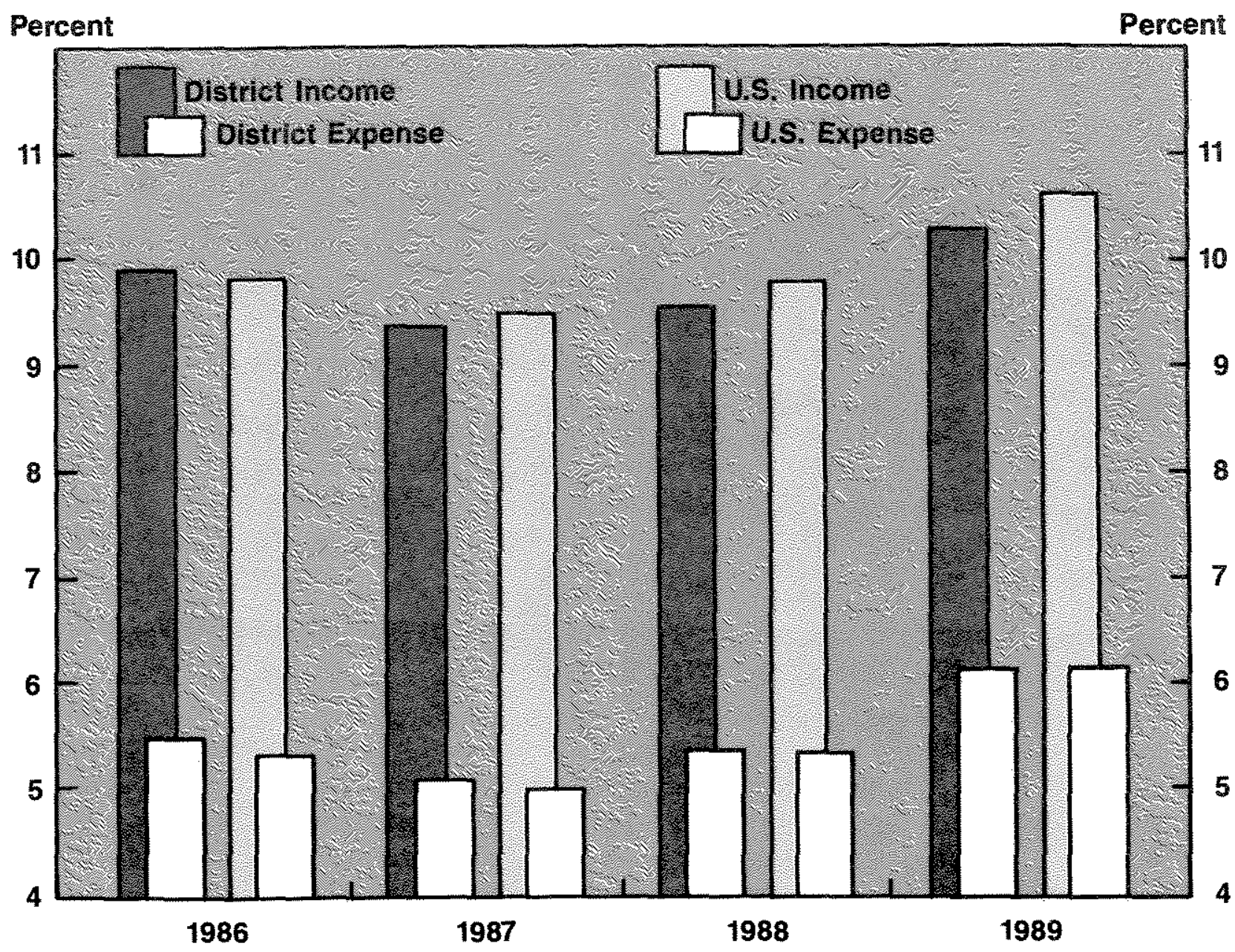

SOURCE: FFIEC Reports of Condition and Income for Commercial Banks, 1986-1989

assets tends to be longer than that of their deposits, rising interest rates impose increasing interest expense at a time when interest income tends to be constant or increasing more slowly, thus exerting downward pressure on net interest margins.

Every asset category of District banks except for one had higher interest expense ratios than their U.S. counterparts in 1989. Moreover, of the four years shown in figure 1, 1989 was the only year in which the overall District average was lower than the national one. The interest expense differentials among District banks and their national peers can be explained by looking at the composition of their interest-bearing liabilities. As illustrated in column 1 of table 3 , deposit interest expense made up a greater share of total interest expense for most categories of District banks than for comparable U.S. banks in 1989. These greater shares can be attributed to the higher proportion of interest- 
Table 3

\section{Composition of Interest Expense and Related Liabilities, 1989}

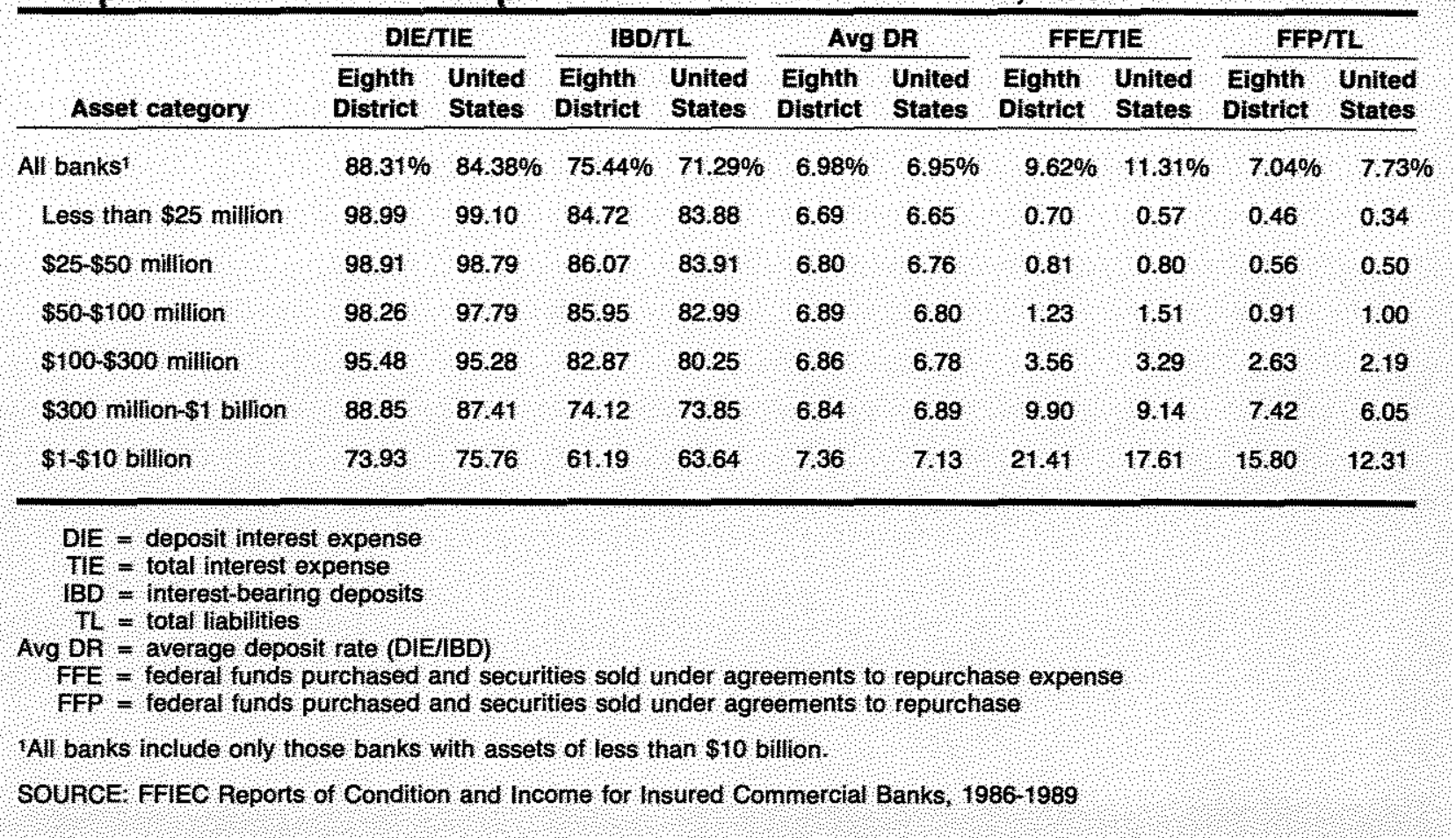

bearing deposits to total liabilities held by Distriet banks (column 3) and the higher average rate paid on those deposits (column 5).

In addition, most District banks paid a higher share of total interest expense for federal funds than their national peers (column 7). ${ }^{\mathrm{s}}$ The majority of District banks held a higher proportion of federal funds purchased and securities sold under agreements to repurchase to total liabilities than U.S. banks overall (column 9). The federal funds rate for 1989 averaged 9.21 percent, approximately 2.2 percentage points higher than the average deposit rate, making federal funds a significantly more expensive source of funding. The higher concentrations of interestbearing deposits and federal funds in their liabilities portfolios and the higher average rates paid by District banks on deposits together accounted for much of the differentials in interest expense ratios between District and U.S. banks from 1986 to 1989.

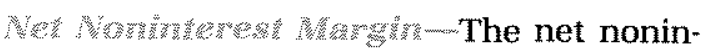
terest margin is an indicator of a bank's operating efficiency and its ability to generate fee income. The net noninterest margin is calculated by subtracting noninterest expense (overhead) from noninterest income and dividing by aver-

\footnotetext{
sFederal funds expense as a percent of total interest expense and federal funds purchased as a percent of total liabilities appear lower for District banks overall than for U.S. banks. This total figure is skewed, however, by the larger proportion of federal funds held by U.S. banks in the $\$ 1$ billion to $\$ 10$ billion asset category and by the larger proportion of U.S. banks in this asset class relative to District banks. These different distributions further itlustrate why it is necessary to break down banks by asset category to assess bank performance more accurately.
} 
age assets. ${ }^{9}$ Because noninterest expense usually exceeds noninterest income, the calculation yields a negative number; it is common practice, however, to report the noninterest margin as a positive number. Smaller net noninterest margins, therefore, indicate better bank performance, all else equal.

Because the net noninterest margin usually is negative and thus depresses earnings, and the income and expense components of this margin tend to be items that banks have more control over than interest income and expense, bank managers increasingly are seeking ways to reduce the net noninterest margin. Excessive overhead frequently is mentioned by banking executives as a barrier to maintaining acceptable profitability levels. Consolidation of operations and increased automation are just two ways the industry is seeking to control the largest portion of overhead, employee salaries and benefits.

In 1989 , as in previous years, all asset categories of Eighth District banks recorded lower net noninterest margins than their national peers. District banks recorded a net noninterest mar gin of 1.93 percent in 1989 vs. 2.12 percent for U.S. banks of comparable size. Despite lower ratios of noninterest income for most categories of banks, District banks continue to record lower net noninterest margins than their U.S. peers because of their consistently lower overhead ratios.

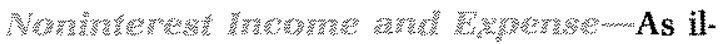
lustrated in table 4, District banks generated a noninterest income to average assets ratio of 1 percent in 1989 compared with 1.22 percent for U.S. banks overall. The pattern of noninterest earnings across asset categories over the last three years continued in 1989, as U.S. banks with assets of less than $\$ 300$ million once again generated more noninterest income relative to average assets than their District peers, while
District banks with assets greater than $\$ 300$ million outperformed their national peers. The lower ratios for smaller District banks relative to larger District banks can be partially attributed to a lesser demand for trust activities and foreign currency transactions in most parts of the District as well as the large number of rural banks that charge no or low fees for many bank services. Lower ratios of off-balance-sheet items to total assets also explain lower noninterest income margins at District banks. ${ }^{10}$

Overall, noninterest expense fell from 1988 to 1989 at both the District and the U.S. level, as many banks were successful in their cost-cutting efforts. Across all asset categories, District banks maintained lower overhead ratios than their national counterparts for all four years shown in table 4 . For District banks, the overhead ratio of 2.93 percent was approximately 13 percent lower than for U.S. banks of comparable size in 1989. These consistently lower overhead ratios can be explained by a number of factors: lower average salaries and benefits in the District; a lack of extensive branching, which keeps overall operating expenses down; and the large proportion of District banks located in nonmetropolitan areas where building, land, rental and maintenance costs are relatively low.

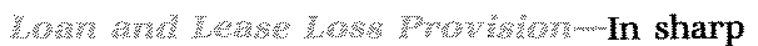
contrast to 1988, when loan and lease loss provisions dropped substantially from their 1987 levels, total loss provisions rose substantially in 1989 for District banks and their U.S. peers. The District loan loss provision totaled $\$ 595$ million in 1989, up 30.5 percent from the 1988 provision of $\$ 456$ million. For U.S. banks of comparable size, the provision rose 21.7 percent to $\$ 13.53$ billion. As table 5 reveals, much of the reversal was concentrated at the largest District and U.S. banks. "The loan loss provision to average assets ratio increased 16.7 percent for District banks with assets of $\$ 300$ million to $\$ 1$ billion, but 56.5 percent for the 13 banks
Noninterest expense is the sum of the costs incurred in the bank's day-to-day operations, which includes employee salaries and benefits, expenses of premises and fixed assets, as well as legal and directors' fees, insurance premiums and advertising and litigation costs. Noninterest income includes income from fiduciary (trust) activities, service charges on deposit accounts, trading gains (losses) from foreign exchange transactions, gains (losses) and fees from assets held in trading accounts, and charges and fees from miscellaneous activities like safe deposit rentals, bank draft and money order sales, and mortgage servicing.
10 Off-balance-sheet items represent obligations by a bank to acquire certain assets or liabilities at a future date provided contractual conditions are met. They include such diverse financial instruments as loan commitments, letters of credit, interest rate swaps and loan sales. Banks usually earn fee income from providing such services, but do not have to hold capital or funding liabilities against the assets until they are actually booked. Off-balance-sheet activities still subject a bank to risks, which is why these items will be included in the new risk-based capital requirements barks will have to meet by the end of 1990 . 
Table 4 Noninterest Income and Noninterest Expense as a Percent of
Average Assets

\begin{tabular}{|c|c|c|c|c|c|c|c|c|}
\hline \multicolumn{9}{|c|}{ Noninterest Income } \\
\hline \multirow[b]{2}{*}{ Asset category } & \multicolumn{2}{|c|}{1989} & \multicolumn{2}{|c|}{1938} & \multicolumn{2}{|c|}{1987} & \multicolumn{2}{|c|}{1986} \\
\hline & $\begin{array}{l}\text { Eighth } \\
\text { District }\end{array}$ & $\begin{array}{l}\text { United } \\
\text { States }\end{array}$ & $\begin{array}{l}\text { Eighth } \\
\text { District }\end{array}$ & $\begin{array}{l}\text { United } \\
\text { States } \\
\end{array}$ & $\begin{array}{l}\text { Eighth } \\
\text { District }\end{array}$ & $\begin{array}{l}\text { United } \\
\text { States }\end{array}$ & $\begin{array}{l}\text { Eighth } \\
\text { District }\end{array}$ & $\begin{array}{l}\text { United } \\
\text { States }\end{array}$ \\
\hline All banks' & $1.00 \%$ & $1.22 \%$ & $0.98 \%$ & $1.20 \%$ & $0.99 \%$ & $1.16 \%$ & $1.01 \%$ & $1.13 \%$ \\
\hline Less than $\$ 25$ million & 0.57 & 1.25 & 0.58 & 0.90 & 0.57 & 0.95 & 0.55 & 0.85 \\
\hline$\$ 25-\$ 50$ million & 0.58 & 0.77 & 0.55 & 0.75 & 0.53 & 0.70 & 0.52 & 0.70 \\
\hline $550-\$ 100$ million & 0.55 & 0.81 & 0.55 & 0.79 & 0.52 & 0.74 & 0.52 & 0.74 \\
\hline$\$ 100-\$ 300$ million & 0.80 & 0.92 & 0.74 & 0.88 & 0.77 & 0.88 & 0.73 & 0.89 \\
\hline$\$ 300$ million $\$ 1$ bilion & 1.17 & 1.13 & 1.23 & $1 \times 12$ & 1.39 & 1.10 & 1.25 & 1.14 \\
\hline$\$ 1-\$ 10$ billion & 150 & 1.47 & 1.51 & 1.49 & 1.52 & 1.44 & 1.69 & 1.39 \\
\hline \multicolumn{9}{|c|}{$\begin{array}{l}\text { Noninterest Expense (Overhead) } \\
1989 \\
1988\end{array}$} \\
\hline Asset category & $\begin{array}{l}\text { Eighth } \\
\text { District }\end{array}$ & $\begin{array}{l}\text { United } \\
\text { States }\end{array}$ & $\begin{array}{l}\text { Eighth } \\
\text { District }\end{array}$ & $\begin{array}{l}\text { United } \\
\text { States }\end{array}$ & $\begin{array}{l}\text { Eighth } \\
\text { Distric: }\end{array}$ & $\begin{array}{l}\text { United } \\
\text { States }\end{array}$ & $\begin{array}{l}\text { Eighth } \\
\text { District }\end{array}$ & $\begin{array}{l}\text { United } \\
\text { States }\end{array}$ \\
\hline All banks ${ }^{1}$ & $2.93 \%$ & $3.34 \%$ & $2.97 \%$ & $3.37 \%$ & $2.98 \%$ & $3.36 \%$ & $2.98 \%$ & $3.34 \%$ \\
\hline Less than $\$ 25$ million & 3.08 & 3.93 & 3.07 & 3.78 & 3.08 & 3.83 & 3,09 & 3.77 \\
\hline$\$ 25-\$ 50$ million & 2.75 & 3.33 & 2.72 & 3.30 & 2.69 & 3.28 & 2.65 & 3.28 \\
\hline$\$ 50-\$ 100$ million & 2.52 & 3.18 & 2.57 & 3.19 & 2,57 & 3.19 & 2.59 & 3.27 \\
\hline$\$ 100-\$ 300$ million & 2.77 & 3.27 & 2.77 & 3.25 & 2.80 & 3.23 & 2.74 & 3.24 \\
\hline$\$ 300$ million- $\$ 1$ billion & 3.20 & 3.31 & 3.32 & 3.40 & 3.37 & 3.38 & 3.46 & 3.45 \\
\hline$\$ 1-\$ 10$ billion & 3.18 & 3.38 & 3.27 & 3.42 & 3.27 & 3.42 & 3.30 & 3.35 \\
\hline
\end{tabular}

1All banks includes only those banks with assets of less than $\$ 10$ billion.

SOURCE: FFIEC Reports of Condition and Income for Insured Commercial Banks, 1986-1989

with assets of $\$ 1$ billion to $\$ 10$ billion; U.S. banks in those categories made more modest additions to their provisions, 1.7 percent and 37.5 percent, respectively. ${ }^{11}$

The substantial increases in the provision ratios for the large District banks were primar ily the result of large provisions taken by Tennessee banks to cover the nonperforming real estate loans of a local developer as well as a large provision at another big District bank to cover remaining exposure to LDC debt. Deteriorating commercial real estate and foreign loan portfolios led to provision increases nationwide as well. Some analysts have suggested that banks that made large increases in provisions in 1987 to cover nonperforming foreign loans were not as vigilant in assessing their growing real estate loan portfolios in 1988 and 1989. Rather than recognizing potential losses in 1988, which would have depressed profits for a second

tThe loss provision ratio for the 43 U.S. banks with assets greater than $\$ 10$ billion almost tripled in 1989 , rising from 0.43 percent to 1.28 percent. 
Table 5

Loan and Lease Loss Provision as a Percent of Average Assets

\begin{tabular}{|c|c|c|c|c|c|c|c|c|}
\hline \multirow[b]{2}{*}{ Asset category } & \multicolumn{2}{|c|}{1989} & \multicolumn{2}{|c|}{1988} & \multicolumn{2}{|c|}{1987} & \multicolumn{2}{|c|}{1986} \\
\hline & $\begin{array}{l}\text { Eighth } \\
\text { District }\end{array}$ & $\begin{array}{l}\text { United } \\
\text { States }\end{array}$ & $\begin{array}{l}\text { Eighth } \\
\text { District }\end{array}$ & $\begin{array}{l}\text { United } \\
\text { States }\end{array}$ & $\begin{array}{l}\text { Eighth } \\
\text { District }\end{array}$ & $\begin{array}{l}\text { United } \\
\text { States }\end{array}$ & $\begin{array}{l}\text { Eighth } \\
\text { Distrlet }\end{array}$ & $\begin{array}{l}\text { United } \\
\text { States }\end{array}$ \\
\hline Al bankst & $0,46 \%$ & $0.69 \%$ & $0.38 \%$ & $0598 \%$ & $0,60 \%$ & $0,79 \%$ & $0.59 \%$ & $077 \%$ \\
\hline Less han $\$ 25$ nilion & 0.28 & 0,49 & 0.30 & 0.62 & 0.49 & 0.83 & 0.68 & 115 \\
\hline$\$ 25 \$ 50$ million & 027 & 0,45 & 0,34 & 0.55 & 0.44 & 0.73 & 0.67 & 097 \\
\hline$\$ 50 \$ 100$ millon & 028 & 0,42 & 030 & 0.49 & 0,41 & 0.61 & 0.62 & 085 \\
\hline$\$ 100 \$ 300$ milion & 0.37 & 0.43 & 0,36 & 0.49 & 0,45 & 0.56 & 0,64 & 075 \\
\hline$\$ 300$ milion $\$ 1$ billon & 042 & 060 & 0,36 & 0.59 & 0,42 & 072 & 0.68 & 0,85 \\
\hline$\$ 1-510$ billion & 072 & 0,88 & 0.46 & 064 & 0.97 & 093 & 0.46 & 0.67 \\
\hline
\end{tabular}

TAll banks includes only those banks with assets of less than sto billon.

SOURCE, FFIEC Reports of Condition and Incone for Instred Commercial Banks, $1986-1989$

straight year, many banks delayed making these large additions until $1989 .{ }^{12}$

It is important to note, however, that District provision ratios were still well below those of their national counterparts in 1989. In addition, provision ratios declined again in 1989 for District and U.S. banks with assets of less than $\$ 100$ million. District banks in these asset categories, which make up more than 80 percent of total District banks, experienced an average decline in the provision ratio of 11.4 percent; U.S. banks in these categories, which represent just over 75 percent of U.S. banks, experienced an 18.2 percent decline.

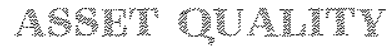

Asset quality was a major determinant in the pattern of earnings for banks nationwide in the 1980s, and 1989 was no exception. The major area of concern, however, has shifted from the quality of foreign loans to the performance of real estate loans. The substantial losses already incurred from foreign lending and the mounting losses from real estate lending have not escaped the notice of shareholders or regulators. Bank stock prices in many parts of the country have

12See Rose (1990).

13The new risk-based capital requirements are discussed briefly in a later section. fallen, reflecting in part banks' volatile earnings pattern of the past few years and the riskaversion of many investors. Regulators, too, are concerned and have refined the tools used to assess loan portfolios. They have also adjusted minimum capital ratios to reflect the riskiness of a bank's asset portfolio. ${ }^{13}$

Asset quality may be gauged by examining the nonperforming loan ratio and the ratio of net loan losses to total loans. The nonperforming loan ratio indicates the current level of problem loans as well as the potential for future loan losses. The ratio of net loan losses to total loans specifies the percentage of loans actually written off the bank's books for a given period.

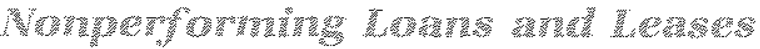

Nonperforming loans comprise loans and lease financing receivables that are 90 days or more past due or in nonaccrual status. ${ }^{14}$ The level of nonperforming loans and leases at District banks totaled $\$ 1.21$ billion at year-end 1989 , a 5.5 percent increase from the level at year-end 1988. Nationally, banks of comparable size experienced a 9.1 percent increase in the level of nonperforming loans.

14Restructured loans and leases that fall into the 90 days or more delinquent status or in nonaccrual status are included as well. 


\section{Table 6}

\section{Nonperforming Loans and Leases as a Percent of Total Loans}

\begin{tabular}{|c|c|c|c|c|c|c|c|c|}
\hline \multirow[b]{2}{*}{ Asset category } & \multicolumn{2}{|c|}{1989} & \multicolumn{2}{|c|}{1988} & \multicolumn{2}{|c|}{1987} & \multicolumn{2}{|c|}{1986} \\
\hline & $\begin{array}{l}\text { Eghth } \\
\text { Distriet }\end{array}$ & $\begin{array}{l}\text { United } \\
\text { States }\end{array}$ & $\begin{array}{l}\text { Elghth } \\
\text { District }\end{array}$ & $\begin{array}{l}\text { United } \\
\text { States }\end{array}$ & $\begin{array}{l}\text { Eighth } \\
\text { District }\end{array}$ & $\begin{array}{l}\text { United } \\
\text { States }\end{array}$ & $\begin{array}{l}\text { Eighth } \\
\text { District }\end{array}$ & $\begin{array}{l}\text { United } \\
\text { States: }\end{array}$ \\
\hline All bankst & $1.60 \%$ & $2.20 \%$ & $1,02 \%$ & 2. $10 \%$ & $2.10 \%$ & $2.40 \%$ & $2.160 \%$ & $240 \%$ \\
\hline Less than 25 millon & 1,71 & 2.31 & 180 & 265 & 212 & 316 & 266 & 376 \\
\hline$\$ 25-\$ 50$ million & 170 & 2,15 & 1,72 & 243 & 2.14 & 275 & 2.61 & 3,19 \\
\hline$\$ 50-\$ 100$ million & 1,47 & 198 & 1,65 & 219 & 2.04 & 2.45 & 246 & 2.93 \\
\hline$\$ 100 \$ 300$ million & 167 & 192 & 170 & 189 & 195 & 220 & 2.04 & 253 \\
\hline$\$ 300$ million $\$ 1$ billon & 1.42 & 2.36 & 125 & 271 & 147 & 2.28 & 233 & 251 \\
\hline$\$ 1 \$ 10$ billion & 165 & 2.27 & 165 & 192 & 2.44 & 241 & 181 & 206 \\
\hline
\end{tabular}

All banks includes only those banks with assets of less than $\$ 10$ billon.

SOURCE FFIEC Reports of Condition and Income for Insured Commercial Banks, $1986-1989$

Despite the rise in the absolute level of nonperforming loans at District banks, the ratio of nonperforming loans and leases to total loans declined from 1.62 percent in 1988 to 1.60 percent in 1989 . As table 6 indicates, the 1989 nonperforming loan ratio for District banks was the lowest of the four years shown. In 1989, only District banks with assets of $\$ 300$ million to $\$ 1$ billion experienced an increase in the nonperforming loan ratio; nonetheless, this category of banks recorded the lowest nonperforming loan ratio (1.42 percent) among District asset categories in 1989 .

In contrast to District banks, U.S. banks experienced an increase in the absolute level of nonperforming loans and the nonperforming loan ratio in 1989. For U.S. banks with assets of less than $\$ 10$ billion, the nonperforming loan ratio increased from 2.10 percent in 1988 to 2.20 percent in 1989. Although the nonperforming loan ratio fell substantially across most asset categories, an 18.2 percent increase in the ratio for banks with assets of $\$ 1$ billion to $\$ 10$ billion was large enough to boost the ratio for all banks. ${ }^{15}$
The distribution of nonperforming loans by loan type for District banks over the past four years is illustrated in figure 2. For the second straight year, real estate loans made up the largest share of nonperforming loans, almost 50 percent at year-end 1989, up from 43 percent in 1988. The rise in the share of nonperforming real estate loans was almost completely offset by a fall in the proportion of nonperforming commercial and industrial loans, from 41 per* cent of nonperforming loans in 1988 to 35 percent in 1989. The share of nonperforming agricultural loans to total nonperforming loans fell again in 1989 to approximately 4 percent, less than half the percentage recorded at year-end 1986. The ratio of nonperforming consumer loans to total nonperforming loans held steady at District banks in 1989 .

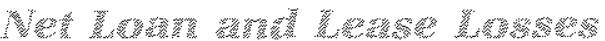

A more direct measure of loan problems than the nonperforming loan ratio is the percentage of loans and leases actually written off a bank's books. Net loan and lease losses are calculated

\footnotetext{
15The nonperforming loan ratio for the nation's largest banks registered its second straight year of improvement in 1989 , declining to 4.41 percent from 4.47 percent in 1988 and 5.26 percent in 1987.
} 
Figure 2

District Distribution of Nonperforming Loans by Loan Type

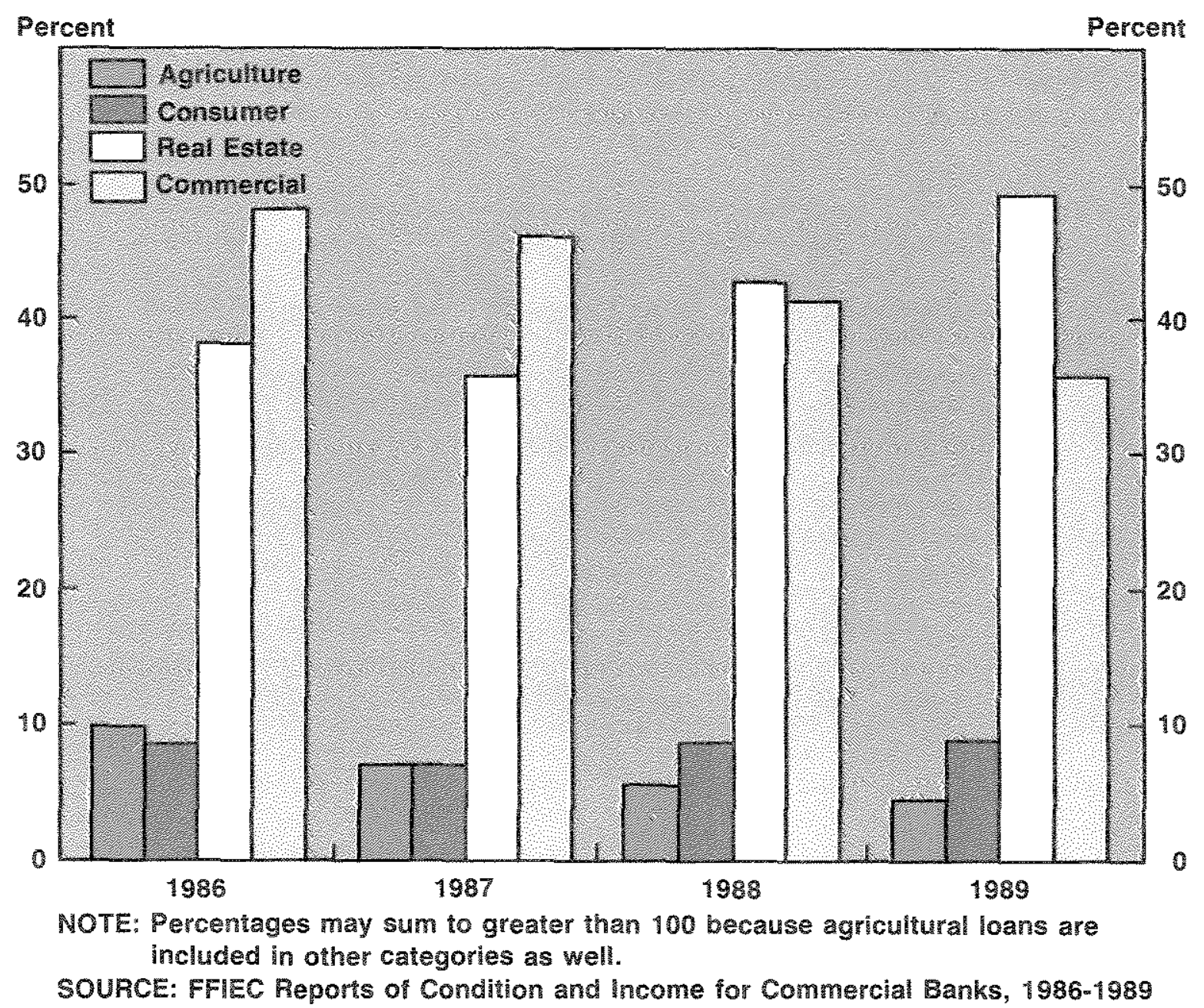

by totaling loan and lease charge-offs and subtracting recoveries over a given period. Net loan and lease losses totaled $\$ 505$ million at District banks in 1989, down almost 2 percent from 1988 net charge-offs. Net charge-offs at U.S. banks of comparable size rose 0.8 percent in 1989 to $\$ 10.4$ billion.
The ratio of net loan and lease losses to total Ioans is an indicator of problem lending in the current year as well as prior years, because of bank management's partial discretion in determining when a loan is deemed uncollectible and is thus written off." As table 7 indicates, the net loan loss ratios for District and comparable

\footnotetext{
16Bank management will adust the loan loss provision in the current year to reflect nonperforming loans; those loans may be carried on a bank's books for years belore a decision is made to write them of Bank supervisors also help decide when to write off loans, and in sact can force a bank to write of a loan that is still pertorming by the
}

bank's stancards. Net loan and lease losses do nol affect current earnings as the ioan loss provision does; rather, they just ather the allowance for loan losses for loan toss reserve), a contra account on the asset side of a bank's balance sheet. 
Table 7

Net Loan and Lease Losses as a Percent of Total Loans

\begin{tabular}{|c|c|c|c|c|c|c|c|c|}
\hline \multirow[b]{2}{*}{ Asset categony } & \multicolumn{2}{|c|}{1989} & \multicolumn{2}{|c|}{1988} & \multicolumn{2}{|c|}{1987} & \multicolumn{2}{|c|}{1986} \\
\hline & $\begin{array}{l}\text { Eighth } \\
\text { District }\end{array}$ & $\begin{array}{l}\text { United } \\
\text { States }\end{array}$ & $\begin{array}{l}\text { Eighth } \\
\text { District }\end{array}$ & $\begin{array}{l}\text { United } \\
\text { States }\end{array}$ & $\begin{array}{l}\text { Eighth } \\
\text { District }\end{array}$ & $\begin{array}{l}\text { United } \\
\text { States }\end{array}$ & $\begin{array}{l}\text { Eighth } \\
\text { District }\end{array}$ & $\begin{array}{l}\text { United } \\
\text { States }\end{array}$ \\
\hline All banks! & $0.67 \%$ & $0.83 \%$ & $0.73 \%$ & $0.87 \%$ & $0.70 \%$ & $0.89 \%$ & $0.88 \%$ & $0.97 \%$ \\
\hline Less than $\$ 25$ million & 0.45 & 0.84 & 0.60 & 114 & 0.95 & 1.50 & 1.33 & 203 \\
\hline$\$ 25-\$ 50$ million & 0.42 & 0.74 & 0.53 & 0.88 & 0.74 & 1.18 & 1.16 & 161 \\
\hline$\$ 50-9100$ million & 0.44 & 0.64 & 0.47 & 0.74 & 0.70 & 0.96 & 1.07 & 135 \\
\hline$\$ 100-\$ 300$ million & 0.53 & 0.60 & 0.50 & 0.66 & 0.67 & 0.78 & 0,99 & 1.02 \\
\hline$\$ 300$ million $\$ 1$ billion & 0.51 & 0.78 & 0.42 & 0.78 & 0.71 & 0.87 & 0.92 & 0.99 \\
\hline \$1-\$10 billion & 1.00 & 0.96 & 1.18 & 0.95 & 0.68 & 0.86 & 0.57 & 0.73 \\
\hline
\end{tabular}

All banks includes only those banks with assels of less than $\$ 10$ billion.

SOUnCE, FFIEC Reports of Condition and heone for Insured Commerclal Banks, $1986-1989$

U.S. banks declined from 1988 to $1989 .{ }^{17}$ District banks wrote off 67 cents for every $\$ 100$ in loans on the books at year-end 1989, compared with 83 cents for U.S. banks of comparable size. EXcept for banks in the $\$ 1$ billion to $\$ 10$ billion asset category, District net loan loss ratios remained well below those of their national counterparts in 1989, as they had for the previous three years.

The net loan loss ratio for District banks declined in 1989 across all but two asset categories; paralleling the rise in the nonperforming loan ratio, the net loan loss ratio rose 21 percent for banks with assets of $\$ 300$ million to $\$ 1$ billion. District banks with assets of $\$ 1$ billion to $\$ 10$ billion experienced a 15.3 percent decline in their net loan loss ratio, as banks that had taken large provisions for LDC loan losses in 1987 wrote off comparatively more of those loans in 1988 than in 1989. For District banks with assets of less than $\$ 50$ million, the net loan loss ratio dechned dramatically again in 1989, reflecting the continuing rebound from agricultural loan losses in the mid-1980s.
The distribution of loan losses by loan type for District and U.S. banks is illustrated in table 8. The data are further separated into two asset categories to illustrate the lending patterns of small vs. large banks, as agricultural loan losses have been primarily concentrated at small banks while foreign loan losses have been incurred by large banks. For banks with assets of less than $\$ 300$ million, losses on commercial and industrial loans once again made up more than 50 percent of total loan losses at both the District and national levels. The share of commercial loan losses at small District and U.S. banks has fallen steadily since 1986, while losses from consumer lending have increased substantially since 1986 at District and U.S. banks of comparable size.

After making up nearly a quarter of District and 20 percent of U.S. loan losses in 1986, the share of agricultural loan losses has dropped dramatically over the past four years, reflecting the rebound in the farm economy and the increase in losses from other types of lending, such as real estate. In contrast to the results at U.S. banks, the share of real estate loan losses

\footnotetext{
${ }^{17}$ Including the nation's largest banks, however, the U.S. net loan loss ratio rose almosi 13 percent in 1989, reflecting LDC loans written off by money center banks and commercial real estate loans written off by some of the country's largesi regional banks.
} 
at small District banks actually fell from 1988 to 1989, although the real estate loss share was roughly the same at both sets of banks. Once again, there were no losses from foreign lending at small District banks in 1989 and minimal losses at the national level.

The largest District banks, with assets of $\$ 300$ million to $\$ 10$ billion, experienced a large increase in the share of commercial and industrial loan losses in 1989, climbing above the 50 percent level for the first time since 1986. Such loan losses at U.S. banks made up less than a third of total loan losses in $\mathbf{1 9 8 9}$, as the ratio continued its steady decline from its 1986 level.

Consumer loan losses accounted for the largest share of total loan losses at U.S. banks in 1989, and the second largest share at District banks. The share of real estate loan losses rose approximately 50 percent at both the District and national level in 1989, and may well surpass consumer and commercial loan loss shares in 1990. The share of agricultural loan losses more than doubled at large District banks in 1989, but still made up the smallest proportion of loan losses at 0.38 percent. After comprising almost a third of loan losses in 1988, foreign loan losses declined to less than 2 percent of total loan losses at large District banks in 1989. Most District banks with outstanding foreign loans wrote off in 1988 the loans for which they took provisions in 1987. The 1989 share of foreign loan losses at U.S. banks of comparable size also fell from 1988, but was twice the District's share.

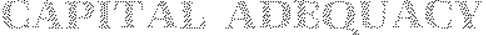

The volatile earnings pattern of banks in recent years, the problem loan portfolios in various parts of the country and the growth of offbalance-sheet items have prompted bank regulators to redefine measurements of the adequacy of financial capital. Banks maintain capital to absorb losses, provide for asset expansion, protect uninsured depositors and promote public confidence in the financial soundness of the banking industry. Since 1985, banks have been

\section{Table 8}

\section{Distribution of Loan Losses}

Banks with assets of less than $\$ 900$ million

\begin{tabular}{|c|c|c|c|c|}
\hline Loan type & 1989 & 1088 & 1987 & 1986 \\
\hline \multicolumn{5}{|l|}{ Drstrot } \\
\hline Agriculture & $370 \%$ & $6,17 \%$ & $14,7 \%$ & $2360 \%$ \\
\hline Commercial & 5372 & 56,16 & 6120 & 66,14 \\
\hline Consumer & 2631 & 2015 & 1023 & 1213 \\
\hline Real estate & 19,84 & 2350 & 2217 & 20.05 \\
\hline Foreign'? & $\mathrm{NA}$ & $\mathbf{N A}$ & NA & 0,12 \\
\hline \multicolumn{5}{|l|}{ United States } \\
\hline Agriculture & $320 \%$ & 4719 & $10,510 \%$ & $1913 \%$ \\
\hline Commercial & 54.76 & 58.60 & 6252 & 69.26 \\
\hline Consumer & 2421 & 21,21 & 18.45 & 15,43 \\
\hline Real estate & 20.41 & 1972 & 1852 & 1484 \\
\hline Forelgn'? & 0.10 & 0.04 & 002 & 0.01 \\
\hline
\end{tabular}

Banks with assets of $\$ 300$ milion to sto bilion

\begin{tabular}{|c|c|c|c|c|}
\hline Loan type & 1089 & 1988 & 1987 & 1986 \\
\hline \multicolumn{5}{|l|}{ Distract } \\
\hline Ageiculture & $0,38 \%$ & $0,15 \%$ & $148 \%$ & $280 \%$ \\
\hline Connercial & 51.36 & 38.34 & 40.68 & 55.23 \\
\hline Consumer & 2111 & 16.30 & 3110 & 28.88 \\
\hline Real estate & 1924 & 12,65 & 15,61 & 1018 \\
\hline Forelgnt & 178 & 2720 & 8.82 & 0.23 \\
\hline \multicolumn{5}{|l|}{ United States } \\
\hline Agrouture & $0.30 \%$ & $0.29 \%$ & $122 \%$ & $3.44 \%$ \\
\hline Oommercial & 31,32 & 36.67 & 3871 & 4691 ? \\
\hline Consumer & 3815 & 32,90 & 35,51 & 36.09 \\
\hline Real estate. & 24.02 & 1638 & 1451 & 1063 \\
\hline foreignt & 413 & 0.28 & 6.40 & 047 \\
\hline
\end{tabular}

Loans held in foreign oftices, Edge and Agleement subside aries and international Bariking Facilties (BF).

$\mathrm{NA}, \mathrm{not}$ apolicable

NOTE Percentages nay sun to more than 100 because some agriculural loans are ncluded in nore than one category.

SOURCE FFEC Reports of Condition and income for hsured Commerciat Banks, $1986-1989$

required by regulators to maintain minimum standards of 5.5 percent primary capital to total adjusted assets and 6 percent total capital to total adjusted assets. ${ }^{18}$ By year-end 1990 , these

capital and includes subordinated notes and debentures, limited-life preferred stock and hat portion of mandatory convertible securities not included in primary capital. Each bank's qualifying secondary capital is added to its primary capital to obtain the total capital level for regulatory purposes. The primary and total capital ratios are obtained by dividing through by average adjusted assets (average assets phus the allowance for loan losses less goodwill). preferred stock, surplus, unoivided profits (retained earn ings), contingency and other capital reserve, qualifying mandatory convertible insifuments, loan and lease loss reserves, minority interests in consolidated subsidiaries, less intangible assets excluding purchased morigage servicing rights. (For the purposes of this paper, only the goodwil portion of intangible assets was deducted.) Secondary capital is limited to 50 percent of primary 


\section{Table 9}

Primary Capital Ratio

\begin{tabular}{|c|c|c|c|c|c|c|c|c|}
\hline \multirow[b]{2}{*}{ Asset category } & \multicolumn{2}{|c|}{1989} & \multicolumn{2}{|c|}{1988} & \multicolumn{2}{|c|}{1987} & \multicolumn{2}{|c|}{1986} \\
\hline & $\begin{array}{l}\text { Eighth } \\
\text { District }\end{array}$ & $\begin{array}{l}\text { United } \\
\text { States }\end{array}$ & $\begin{array}{l}\text { Eghth } \\
\text { District }\end{array}$ & $\begin{array}{l}\text { United } \\
\text { States }\end{array}$ & $\begin{array}{l}\text { Eighth } \\
\text { District }\end{array}$ & $\begin{array}{l}\text { United } \\
\text { States }\end{array}$ & $\begin{array}{l}\text { Eighth } \\
\text { District }\end{array}$ & $\begin{array}{l}\text { United } \\
\text { States }\end{array}$ \\
\hline All banks & $871 \%$ & $8.25 \%$ & $872 \%$ & $8.12 \%$ & $8.72 \%$ & $811 \%$ & $8.47 \%$ & $197 \%$ \\
\hline Less hat $\$ 25$ milion & 10,38 & 1100 & 10,43 & 1080 & 10.11 & 10,58 & 9.97 & 10.36 \\
\hline$\$ 25-\$ 50$ million & 9.84 & 9.92 & 968 & 965 & 9.52 & 9.48 & 9.27 & 9.30 \\
\hline$\$ 50-\$ 100$ million & 9.67 & 949 & 948 & 9.26 & 9.35 & 906 & 9.08 & 8.82 \\
\hline $5100-5300$ millon & 8.85 & 8.76 & 8.85 & 8.63 & 871 & 8.51 & 8.50 & 8.26 \\
\hline$\$ 300$ nilition $\$ 1$ bilion & 872 & 823 & 8.55 & 786 & 8.50 & 785 & 8.30 & 781 \\
\hline$\$ 1 \$ 10$ blilon & 753 & 753 & 766 & 745 & 789 & 746 & 752 & 731 \\
\hline
\end{tabular}

All banks includes only those banks with assets of less than $\$ 10$ billion.

SOURCE, FFIEC Reports of Condition and Income for Insured Commercial Banks, 1986,1989

standards will be replaced by a new core capital to total assets ratio (leverage ratio) and capital ratios based on risk-adjusted assets, standards designed to adjust capital requirements to the credit risk of assets and off-balance-sheet items. ${ }^{19}$

Both District banks and their national counterparts continued to register average primary capital ratios well above the minimum standard in 1989. As table 9 indicates, District banks averaged a primary capital ratio of 8.71 percent in 1989 , just slightly lower than that achieved in 1987 and 1988. All District bank categories except for the smallest (assets of less than $\$ 25$ million) and the largest ( $\$ 1$ billion to $\$ 10$ billion) experienced increases or no change in their primary capital ratios from 1988 to 1989 . The District's smallest banks, like their national peers, once again recorded an average primary capital ratio well above the total bank average in 1989. Unlike the previous three years, when they had an average ratio substantially higher than that of their national counterparts, the largest District banks in 1989 averaged the same rate as their national peers, 7.53 percent.

As of December 1989, 11 banks, or 0.9 percent of all District banks, registered primary capital ratios below the regulatory minimum, an increase from 1988 when 0.5 percent failed to meet the requirement. Nationally, 358 or 2.9 percent of U.S. banks of comparable size recorded deficient primary capital ratios at yearend 1989, compared with 498 banks or 3.9 percent of such banks at year-end 1988.

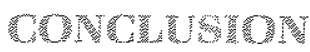

Despite some trouble spots, Eighth District banks once again outperformed their national peers in measures of profitability, asset quality and capital adequacy in 1989. Most District

\footnotetext{
19The risk-based capital guidelines establish a systematic framework in which differences in risk profiles among banking institutions can be assessed in defining regulatory capital. Assets as well as off-balance-sheet items will be assigned weights of $0,20,50$ or 100 percent based on their riskiness as determined by tegulators. Through 1990 , banks have the option of meeting the 5.5 percent primary capital and 6 percent total capital ratios, or the transition capital reguirements effective at year-end 1990 of 7.25 percent qualifying capital to risk-adjusted assets, 3.625
}

percent Tier 1 capital to risk-adjusted assets and 3 percent Tier 1 capital to total assets (leverage ratio). By year-end 1992, all banks will be required to meet the 3 percent leverage ratio, an 8 percent capital to risk-adjusted assets ratio and a 4 percent Tier 1 capital to risk-adjusted assets ratio. 
banks registered higher profitability ratios than their U.S. peers, even though the major determinant of ROA, the net interest margin, remained lower in the District in 1989. Lower loan loss provision ratios and net noninterest margins at District banks more than compensated for lower net interest margins, resulting in higher ROA and ROE.

In contrast to comparable U.S. banks, asset quality continued to improve at District banks in 1989 , as both the nonperforming loan ratio and the net charge-off rate declined. Both District and U.S. banks, however, are experiencing increases in problem real estate loans and a substantial decline in asset quality could mater:alize in 1990. In addition to imposing new risksensitive capital requirements on banks, regulators will be keeping a close eye on real estate portfolios.

Most District and U.S. banks had capital ratios substantially in excess of current minimum standards in 1989, and the majority of small banks should have no trouble meeting the new riskbased capital requirements and leverage ratio. Larger banks with substantial off-balance-sheet exposure may have considerably more trouble meeting the new requirements, as those items are being added to the asset base of banks and are being assigned higher risk rates than some traditional assets like home mortgages and U.S. government securities.

As the 1990s begin, bankers across the country will be faced with economic uncertainty, a changing regulatory environment and growing problem loans, a climate not unlike that of the early 1980s. Eighth District banks, with solid profitability ratios, good asset quality and strong capital positions, are poised to weather the changes of this decade as they did the changes of the last.

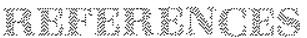

Clark, Michelle A. "Bank Performance in 1989: The Pluses and Minuses," Pieces of Eight, Federal Reserve Bank of St. Louis (June 1990).

Karrenbrock, Jeffrey D. "The U.S. and District Agricultural Economy: Continued Strength in 1989," this Review (May/June 1990).

Rose, Sanford. "Mounting Loan-Loss Provisions Weaken Regional Bank Profits," The American Banker, (February 6, 1990). 